\title{
PHYSIOLOGICAL PARAMETERS OF THE STATE OF Pinus pallasiana D. DON IN DIFFERENT FOREST-GROWTH CONDITIONS IN RAVINE VIYSKOVYI
}

\author{
VALENTINA BESSONOVA $\otimes^{1}$, TETIANA YUSYPIVA ${ }^{2}$ \\ ${ }^{1}$ Department of Garden and Park Architecture, Dnipro State Agrarian and Economic University, S. Efremov Str., 25, Dnipro, 49600, Ukraine; e-mail: valenti- \\ nabessonova492@gmail.com \\ ${ }^{2}$ Department of Physiology and Introduction of Plants, Oles Honchar Dnipro National University, Gagarin Ave., 72, Dnipro, 49010, Ukraine; e-mail \\ JusypivaTatjana@i.ua
}

$\triangle$ Corresponding author

Received: 22 July 2019 / Accepted: 15 November 2019

\begin{abstract}
Bessonova V., Yusypiva T.: Physiological parameters of the Pinus pallasiana D. Don in different forest-growth conditions in Ravine Viyskovyi. Ekológia (Bratislava), Vol. 40, No. 2, p. 137-144, 2021.

The influence of different forest-growth conditions on the ecological and physiological parameters of Pinus pallasiana D. Don plants growing in antierosion planting is investigated. The experimental sites are located in the thalweg (test area 1) and on the slope of southern exposure in the lower middle, and upper parts (test areas 2-4) of Ravine Viyskovyi (steppe zone of Ukraine). Forest-growth conditions are clay-loam soil ( $\mathrm{CL}_{2}$ ) (mesophilic, fresh soil), $\mathrm{CL}_{1-2}$ (xeromesophilic, rather fresh), $\mathrm{CL}_{1}$ (mesoxerophilic, somewhat dry or semi-arid), and $\mathrm{CL}_{0-1}$ (xerophilic, arid) correspondently. It was shown that the growth rates of trees, the growth rate of lateral (scaffold) branches in length and thickness, needle-packing coefficient, and needle surface area of annual shoots are maximal in P. pallasiana in the thalweg in conditions of the best water supply and minimal in arid and semi-arid conditions of growth. The research revealed that the highest content of total water in the needles is characteristic of plants of fresh forest plant conditions and the smallest in arid and semi-arid areas (test areas 3 and 4), which is consistent with the forest-vegetation conditions.

Sufficient contents of potassium, calcium, and magnesium in all areas and phosphorus in three areas except the middle part of the slope were found in the needles of P. pallasiana. However, insufficient content of nitrogen was found in the needles, especially in the trees of the middle part of the slope, which, together with low water supply, could cause the most significant slowdown in the growth of $P$. pallasiana plants precisely on this experimental site. A correlation was established between the indices of plant growth and the content of water and nutrients.
\end{abstract}

Key words: ravine, Pinus pallasiana D. Don, forest-growth conditions, growth of shoots, needle, contents of nutrients.

\section{Introduction}

Afforestation of steppes should become the basis for creating an environmentally sustainable environment, a basic element in preventing destructive phenomena and processes that are characteristic of the steppe (Furdichko, 2006; Çalişkan, Boydak, 2017). Under these conditions forests perform important functions of environmental optimization, environmental regulation, and environmental protection, i.e., erosion control, soil protection, and hydrological regulation.

Complex and varied forest-growth conditions on the slopes of the ravines (exposition, steepness, class of soil removal, different water and temperature regimes, etc.) require careful selection of wood species for the creation of this type of forest plantation (Moroz, 1972; Gorejko, 1992). It is the woody plants that have a well-developed above-ground part and a powerful root system that fixes erosion, should play a significant role in the transformation of the surface runoff into the base runoff.

The slopes of the ravines are mostly planted with soboliferous wood and bush species (Robinia pseudoacacia L., Alnus incana
(L.) Moench., Hippophae rhamnoides L., Elaeagnus angustifolia L., Prunus spinosa L., etc.). Nevertheless, conifers are often used, because they are tolerant to drought tolerance and can adapt to different soil fertility (Gorejko, 1992). The experience of using coniferous plants on eroded slopes suggests that they are characterized by high meliorative properties due to their rapid growth, soil-fixing ability of roots, and the formation of a powerful forest litter (Moroz, 1972; Olkhovsky, 1984).

Morozov (1931) defines pine as an evident xerophyte, as it needs little water, it has small surface of the foliar organs due to the very shape of a needle and its anatomical structure, and, on the other hand, it has a large area of the root system. However, the task of using Pinus pallasiana in anti-erosion plantations of the Northern Steppe of Ukraine has not been studied. For comprehensive environmental monitoring of forest plantations using this species, not only forest-map examination but also physiological analysis of the vitality of plants is required.

The purpose of this study is to compare physiological parameters of Pinus pallasiana such as the growth of the tree and lateral branches growth, the content of the total water, and elements of

(c) The Author(s) 2021. This is an open access article distributed under the terms of the CC BY-NC-ND license.

https://content.sciendo.com/view/journals/eko/eko-overview.xml 

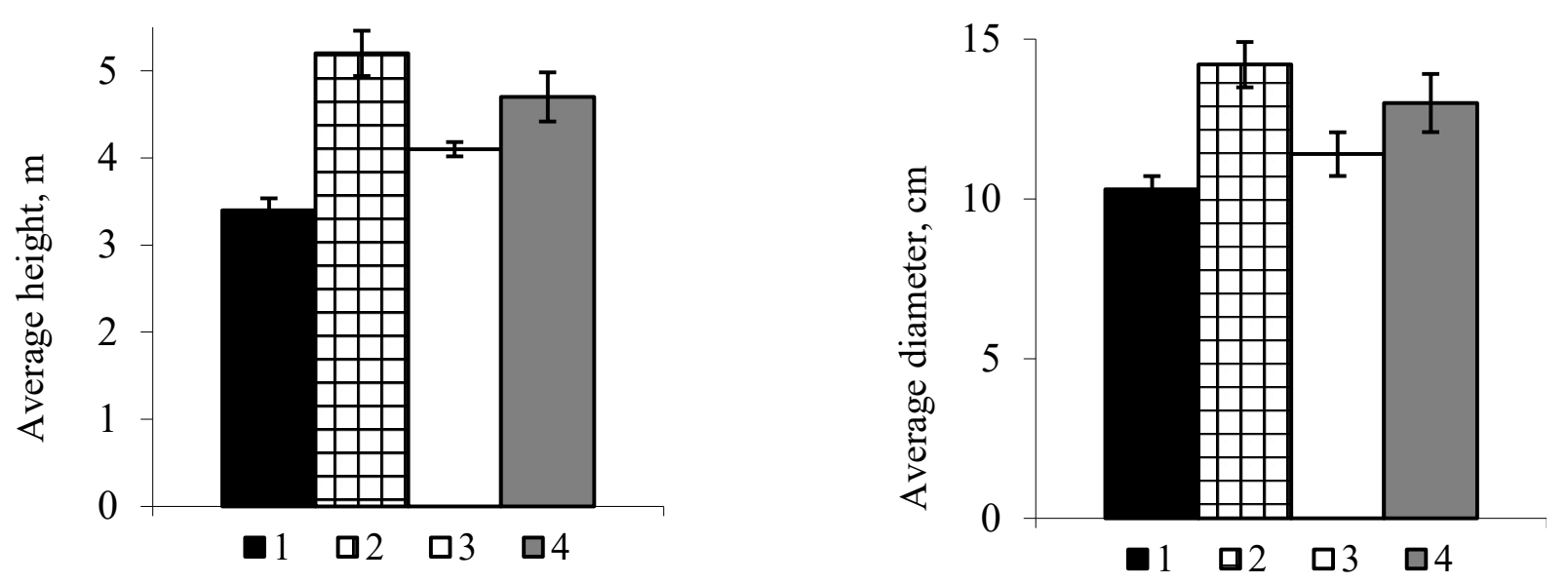

Fig. 1. Average height and average diameter of the P. pallasiana plants in different forest-growth conditions: 1, 2, 3, 4 - test areas.
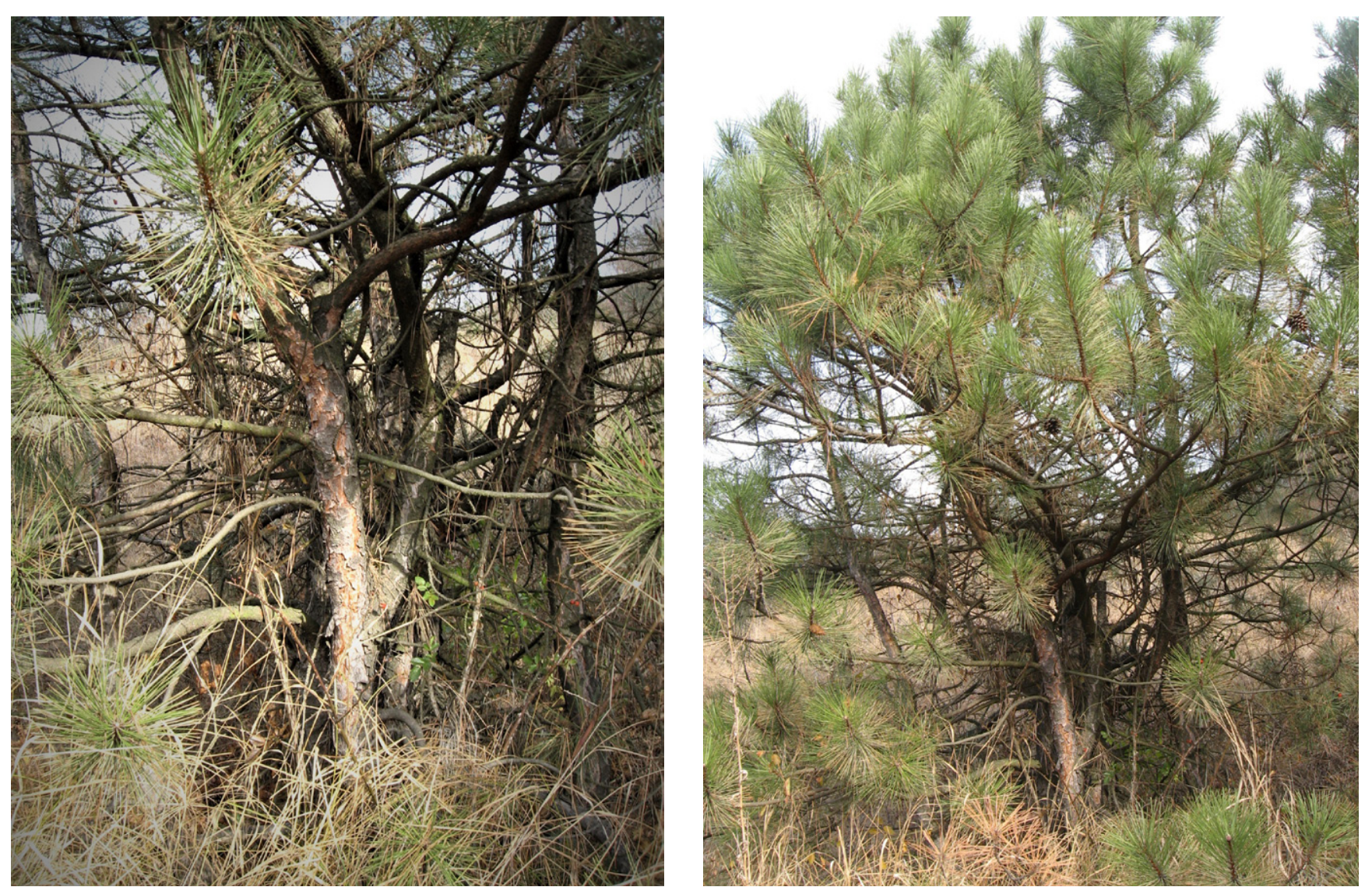

Fig. 2. Multitrunk trees in test area 1 (thalweg).

mineral nutrition in the needles in correlation with the growth in various forest-growth conditions of anti-erosion plantings.

\section{Material and methods}

The research was conducted in Ravine Viyskovyi, which is located on the right side of the Dnipro river near Viyskove village in
Solonyansky district of the Dnipropetrovsk region. It preserved both natural forest phytocenoses and artificial anti-erosion forest stands (Bessonova et al., 2015, 2018a,b).

The research object was the planting of Pinus pallasiana on the slope of the southern exposure. Forest plantings are created on terraces, perpendicular to the surface of the slope of the ravine. Age of planting is 25-27 years. 
Any ravine is a very complex from the microclimatic point of view. According to Belgard (1971), the microclimate of a ravine changes literally at every step. The slopes of the southern exposure have the most pronounced continental climate; they are warmer and drier and characterized by more stringent forest planting conditions.

The climate of the region is characterized by high levels of solar radiation and summer droughts (Tsvetkova, 2013). In the context of global warming (Hughes, 2000; Aber et al., 2001; Walther, 2003), a hydrothermal trend can greatly aggravate the growth of plants. The most optimal forest-growth conditions are formed in the thalweg and the lower part of the slope, where the moisture conditions are better. In the upper parts of the slope, the dryness of soils increases (Belgard, 1950). It should be noted that the summer months in the study area are characterized by a small amount of precipitation (around $420-450 \mathrm{~mm}$ ) and prolonged sunny periods without rain. Moisture factor is 0.67 . In the period of July-September of the experimental period, there was almost no rain.

The experimental plots were selected in different forestgrowth conditions. Test area 1 is located in the thalweg on its slightly elevated flat part at a distance of about $35 \mathrm{~m}$ from the stream, which flows in a well with a depth of $2 \mathrm{~m}$. The soil moisture of this site is ground and atmospheric. Forest-growth conditions are $\mathrm{CL}_{2}$ (mesophilic, fresh). The second, third, and fourth test sites are located in the lower, middle, and upper parts of the slope, respectively. The types of forest-growth conditions are $\mathrm{CL}_{1-2}$ (xeromesophilic, rather fresh), $\mathrm{CL}_{1}$ (mesoxerophilic, somewhat dry, or semi-arid), and $\mathrm{CL}_{0-1}$ (xerophilic, arid) (Belgard, 1971; Tsvetkova, 2013), respectively. The other characteristics are atmospheric-transit moistening; the mechanical composition of the soil is clay loam; and soil is ordinary black soil, low humus, mildly alkaline, high carbonate soil, medium loamy on wood loams, medium washed off (Belgard, 1971).

Measurements of the diameter of the trunks were carried out at an altitude of $1.3 \mathrm{~m}$ with a dimensional fork of height with an altimeter. The average height and average diameter of the treestands of experimental areas were calculated according to Anuchin (1982).

Parameters such as the annual growth of trees, the length of annual shoots, and the number of pairs of needles on them were determined. The relative needle packing of annual shoots (the number of needles per $\mathrm{cm}$ of the length of the shoots) was calculated (Tarkhanov, Biryukov, 2012). The annual growth of trees was measured on 20 model trees, the growth of shoots in these trees, on 5 model branches, and coverage on 100 one-year increments in September. The needles for determining the amount of total water were taken during the spring-summer period. Its content was calculated as a percentage (\%) on the wet weight (Hrytsaenko et al., 2003). The drying was carried out at the temperature of $105^{\circ} \mathrm{C}$ in a drying cabinet.

The content of phosphorus, potassium, and nitrogen was determined from one analytical test (Karasyuk et al., 2001): phosphorus and nitrogen by photocolorimetric method on KFK-301-ZOMS (phosphorus with iron-molybdate reagent, nitrogen with Nessler's reagent) and potassium by photometric method using Flame Photometer Jenway PFP 7. The content of magnesium and calcium was determined per one specimen by volumetric method (Bessonova, 2001). Samples of needles for analysis were taken from the southeastern side of the crown at an altitude of $2 \mathrm{~m}$.
The results of the experiment were processed with mathematical statistics method using Microsoft Office Excel 2007. The arithmetic mean error was calculated. Student's t-test $(\mathrm{p}<0.05)$ was used to compare the indices in different forest-growth conditions.

\section{Results and discussion}

Indices of average height and average diameter of trunks are greatest in the trees of the lower third of the slope (Fig. 1). It is impossible to estimate them in the thalweg properly. This is due to the fact that because of anthropogenic interference in most of the trees in this area, the trunk was cut off at its base. After that, 2-3 lower branches changed the direction of growth and took on the role of trunks (Fig. 2). Usually, each of them is thinner than the trunks of plants in other areas. As shown in Fig. 2, the upper parts of the trunks continue to be cut. In the middle and upper areas of the slope, these figures are lower than those in the lower area. The difference between the data obtained in these two areas is insignificant, although, as indicated earlier, on the upper area of the slope (Bessonova et al., 2015), there are more trees, which are slightly taller and have a larger diameter than there are in the middle area, despite less humid soil.

Height growth rate of $P$. pallasiana trees was different in experimental areas (Table 1). It was the largest in plants in the thalweg but somewhat lower in the lower area of the slope. Annual growth rate is much lower in test areas 3 and 4, especially in area 3 (the average part of the slope is $65.8 \%$ and $76.0 \%$, respectively, with respect to the given index in plants of thalweg). A similar pattern was observed when comparing annual increments of lateral branches of the trees in different forest-growth conditions (Table 1). They were the highest in the best soil moisture conditions (thalweg) and the lowest in the middle and upper areas of the slope. In these test areas, the length branch growth rate was $51.1 \%$, which makes only $52.3 \%$ of the indicator in the trees of thalweg. The difference between the increments of annual shoot growth of trees in these areas is statistically insignificant. The difference between the values of the thickness of one-year shoots on experimental sites is less than the value of their length increments; it does not show significant difference from the reference value in the plants in the lower area of the slope (Table 1).

Our data are consistent with the results obtained by Shvets (2010), who states that the conditions of the fresh hump are sufficiently comfortable for $P$. pallasiana plantations, since in them the average wood stock is somewhat higher than that in other forest-growth conditions, as forest stands grow faster.

Significantly greater differences in the trees in the areas with different water supply were found in values of amount of needles on the annual increment. The maximum number bundles of needles is found on the plants in the thalweg. In the other areas of the slope, it is much lower, with the lowest number in the low area -1.63 times, the average area -3.12 times, and the upper area -2.52 times, compared with the values in the thalweg. The needle-packing coefficient is also the largest in plants of thalweg and the lowest in the trees of the middle part of the slope. Differences in the needle-packing coefficient values in the bottom and upper areas of the slope compared to those in the thalweg plants are insignificant at $p<0.05$. The surface area of the needle on the annual shoot is also the highest in the plants of thalweg and the smallest in the trees in test areas 2 and 3 (23.1 and 25.9\%, as com- 
Table 1. Annual height growth of trees increment of lateral branches of $P$. pallasiana in different forest-growth conditions $(\mathrm{M} \pm \mathrm{m})$.

\begin{tabular}{|c|c|c|c|c|c|c|}
\hline Test area & $\begin{array}{l}\text { Height growth } \\
\text { increment, } \mathrm{cm} \\
\quad(\mathrm{n}=20)\end{array}$ & $\begin{array}{l}\% \text { of the } \\
\text { value in the } \\
\text { thalweg }\end{array}$ & $\begin{array}{l}\text { Length increment of } \\
\text { lateral branches, } \mathrm{cm} \\
\qquad(\mathrm{n}=100)\end{array}$ & $\begin{array}{l}\% \text { of the } \\
\text { value in the } \\
\text { thalweg }\end{array}$ & $\begin{array}{l}\text { Thickness of the one-year } \\
\text { shoot increment, mm } \\
(\mathrm{n}=100)\end{array}$ & $\begin{array}{l}\% \text { of the } \\
\text { value in } \\
\text { the thalweg }\end{array}$ \\
\hline Test area 1 & $37.51 \pm 0.79$ & & $14.20 \pm 0.63$ & & $6.44 \pm 0.21$ & \\
\hline Test area 2 & $34.32 \pm 0.54^{*}$ & 91.5 & $10.84 \pm 0.52^{\star}$ & 76.3 & $5.87 \pm 0.25$ & 91.1 \\
\hline Test area 3 & $24.70 \pm 0.80^{*}$ & 65.8 & $7.25 \pm 0.40^{*}$ & 51.1 & $4.51 \pm 0.17^{\star}$ & 70.0 \\
\hline Test area 4 & $28.51 \pm 0.61^{\star}$ & 76.0 & $7.42 \pm 0.32^{\star}$ & 52.3 & $5.32 \pm 0.18^{\star}$ & 82.6 \\
\hline
\end{tabular}

Note: ${ }^{\star}$ Differ significantly from test area $1(\mathrm{p}<0.05)$.

Table 2. Influence of forest-growth conditions on needle-packing rate of the shoots of $P$. pallasiana $(\mathrm{M} \pm \mathrm{m}, \mathrm{n}=100)$.

\begin{tabular}{|c|c|c|c|}
\hline Test area & $\begin{array}{c}\text { Number of bundles of needles on annual } \\
\text { increment, units }\end{array}$ & Needle-packing coefficient & $\begin{array}{c}\text { Needle surface area on annual shoot, } \\
\mathbf{c m}^{2}\end{array}$ \\
\hline Test area 1 & $86.90 \pm 3.21$ & $6.15 \pm 1.12$ & $4096.46 \pm 312.21$ \\
\hline Test area 2 & $53.30 \pm 2.14^{\star}$ & $4.92 \pm 0.45$ & $2105.83 \pm 193.17^{\star}$ \\
\hline Test area 3 & $27.81 \pm 1.17^{\star}$ & $3.86 \pm 0.30^{\star}$ & $944.98 \pm 78.84^{\star}$ \\
\hline Test area 4 & $34.48 \pm 2.42^{\star}$ & $4.64 \pm 0.22$ & $1060.26 \pm 101.69$ \\
\hline
\end{tabular}

Note: ${ }^{\star}$ Differ significantly from test area $1(\mathrm{p}<0.05)$.

pared to the indicator in the thalweg). Such a significant decrease in the assimilation surface may be one of the causes of inhibition of the photosynthetic function of plants in stressful conditions of existence, taking into account simultaneous reduction of the content of the main and auxiliary pigments of photosynthesis in the needles of trees in arid locations (Table 2).

Plant growth and development is known to be dependent on water supply. The water content and its properties are of great importance, and changes in these parameters should strongly affect the life of plants in general (Correia et al., 2001; Colom, Vazzana, 2001). The effect of adverse conditions of humidification on the water regime of plants can be direct due to the decrease in the amount of free water content in the tissues (Zaitseva, Syrovatko, 2016), as well as changes in metabolism (Samuilov, 1971). Consequently, the analysis of the total water content in the tissues, although it does not fully reflect changes in water metabolism, provides an opportunity to understand how the adverse conditions of moisture affect the maintenance of the water supply of the pine needles of $P$. pallasiana.

Comparison of the amount of total water content in the needles of $P$. pallasiana in the test areas (Table 3) indicates that it is the highest in the plants of the thalweg, where the type of moistening is ground and atmospheric $\left(\mathrm{CL}_{2}\right)$. On this site, the slightest fluctuations of the needle water supply rate during the experimental period are observed. Somewhat larger changes in this index occur in the trees at the bottom of the slope $\left(\mathrm{CL}_{1-2}\right)$. The moisture content varies from 51.0 to $57.4 \%$. The most significant changes in the amount of total water are observed in the needles of trees growing in the upper and middle areas of the slope (forest-growth conditions $\mathrm{CL}_{1}-\mathrm{CL}_{0-1}$ ).

As Table 3 shows, the needles of the plants on the upper slope are characterized by the minimum moisture content, although the difference with the data obtained in the trees of the middle area of the slope is small. Soil aridity index causes a decrease in the total water content in the P. pallasiana needles on experimental sites, especially in dry forest-growth conditions. Velinova and
Naydenova (2008) ascertained that due to insufficient moisture content, there was a decrease in the water content of $P$. sylvestris L. and P. nigra Arn. and to a greater extent of $P$. sylvestris. Other researchers (Fotelli et al., 2000; Bessonova et al., 1975, 2016) indicate the decrease in moisture content in the leaves of plants as the water supply of soil drops.

Water scarcity stress, permanent or temporary, limits plant growth significantly more than other environmental factors (Chao et al., 2008; Ponomaryova et al., 2009). Zahner and Donnely (1967) established correlations between the height and thickness growth of $P$. resinosa Sol. ex Aiton and the amount of available water. In the conditions of water shortage, plant growth is suppressed (Smirnoff, 1998) at different levels from cell to general (Colom, Vazzana, 2001). According to Ponomaryova et al. (2009), the most optimal value of moisture content of conifers in the experiment is the range between the lowest moisture content and the discontinuous capillary moisture. Reduced moisture content below discontinuous capillary moisture values negatively affects the growth and anatomical structure of trees. Prolonged water shortage reduces the growth of leaves of many plant species (Thakur, Kaur, 2001; Thakur, Sood, 2005), causing formation of smaller size of leaves (Pane, Golstein, 2001). Similar results of the influence of different water supply on plant growth processes were obtained in our study. This applies both to the suppression of the height growth of trees, and the annual increment of branches, the number of needles on them, and the area of needles on the annual increment of shoots.

In forest soils, it often happens that there is a shortage of physiologically available compounds of nitrogen, phosphorus, and potassium, sometimes magnesium (Pietrzykowski et al., 2013; Rausch, Bucher, 2002). Mineral nutrition plays a significant role in the growth and productivity of forest crops (Mercado et al., 2017). The smallest values of the thickness of the annual ring and the share of late wood of $P$. sylvestris are characteristic for the treestands, which grow on non-fertile soils, compared with the treestands on the soils of low and high fertility (Aleinik- 
Table 3. Influence of forest-growth conditions on water content in the needles of $P$. pallasiana, $\%$ of the wet weight $(M \pm m, n=4)$.

\begin{tabular}{|c|c|c|c|c|c|}
\hline Test area & May & June & July & August & September \\
\hline Test area 1 & $59.25 \pm 1.20$ & $57.61 \pm 0.85$ & $55.42 \pm 0.72$ & $54.30 \pm 0.84$ & $56.81 \pm 0.67$ \\
\hline Test area 2 & $57.36 \pm 0.80$ & $55.54 \pm 0.72$ & $52.50 \pm 0.81$ & $50.00 \pm 0.65^{\star}$ & $53.11 \pm 0.63^{\star}$ \\
\hline Test area 3 & $50.12 \pm 1.27^{\star}$ & $49.30 \pm 0.61^{\star}$ & $49.60 \pm 0.64^{*}$ & $47.31 \pm 0.72^{\star}$ & $49.70 \pm 0.60^{\star}$ \\
\hline Test area 4 & $49.11 \pm 0.63^{\star}$ & $47.32 \pm 0.56^{\star}$ & $47.16 \pm 0.71^{\star}$ & $45.36 \pm 0.66^{\star}$ & $47.62 \pm 0.64^{*}$ \\
\hline
\end{tabular}

Note: ${ }^{\star}$ Differ significantly from test area $1(\mathrm{p}<0.05)$.

Table 4. Influence of forest-growth conditions on the content of nutrients in the needles of $P$. pallasiana, \% oven-dry weight $(\mathrm{M} \pm \mathrm{m}, \mathrm{n}=4)$.

\begin{tabular}{|c|c|c|c|c|c|}
\hline Test area & $\mathrm{N}$ & $\mathrm{P}$ & $\mathrm{K}$ & $\mathrm{Mg}$ & $\mathrm{Ca}$ \\
\hline Test area 1 & $2.11 \pm 0.10$ & $0.32 \pm 0.02$ & $1.63 \pm 0.09$ & $0.29 \pm 0.01$ & $0.72 \pm 0.02$ \\
\hline Test area 2 & $1.85 \pm 0.11$ & $0.27 \pm 0.04$ & $1.46 \pm 0.11$ & $0.24 \pm 0.02$ & $0.72 \pm 0.03$ \\
\hline Test area 3 & $1.32 \pm 0.09^{\star}$ & $0.19 \pm 0.02^{\star}$ & $1.10 \pm 0.10^{\star}$ & $0.19 \pm 0.02^{\star}$ & $0.53 \pm 0.03^{\star}$ \\
\hline Test area 4 & $1.57 \pm 0.07^{\star}$ & $0.24 \pm 0.01^{\star}$ & $1.32 \pm 0.08^{\star}$ & $0.22 \pm 0.02^{\star}$ & $0.64 \pm 0.02^{\star}$ \\
\hline
\end{tabular}

Note: ${ }^{\star}$ Differ significantly from test area $1(\mathrm{p}<0.05)$.

ovas, Grigaliūnas, 2006). Mineral elements are either structural components of functional systems (photosynthetic apparatus, respiratory chain, protein synthesis centers, and other important compounds) or a component of enzyme systems responsible for the functioning of these systems, or their cofactors (Hawkesford et al., 2012; Netzer et al., 2018; Tang et al., 2018).

The amount of mineral substances in organs of tree plants is influenced by the conditions of growth, especially the moisture content in the soil (Lir et al., 1974). Odukalets and Musienko (2012) indicate that the state of $P$. sylvestris in anti-erosion plantings depends on the content of the mineral elements of the soil and the ability of plants to absorb them, which is determined by the age of the plants, the exposure of the slope, and type of soil.

Leaf diagnostics is often used as a means of studying the nutritional status of trees (Shcherbakov, 1964; Churagulova, 2004; Yan et al., 2016). According to our data (Table 4), phosphorus content showed the most diverse values among all mineral nutrition elements in the needles of plants of different forest-growth conditions. The highest amount of this element is in the plants of the thalweg. The minimum value (59.4\% of that in the thalweg) is determined in the trees of the middle part of the slope, which is explained by the greatest soil removal. Needles of the upper part of the slope contain slightly more phosphorus than in its middle area.

The content of other elements presents a similar pattern. Thus, the amount of nitrogen in the needles in the middle part of the slope is $62.6 \%$ of the values in the thalweg, while the upper one it is $74.4 \%$, and for magnesium, these figures are 65.5 and $75.9 \%$, respectively (Fig. 3). The contents of potassium and calcium show a smaller difference between the test areas. The difference in the concentration of investigated elements of mineral

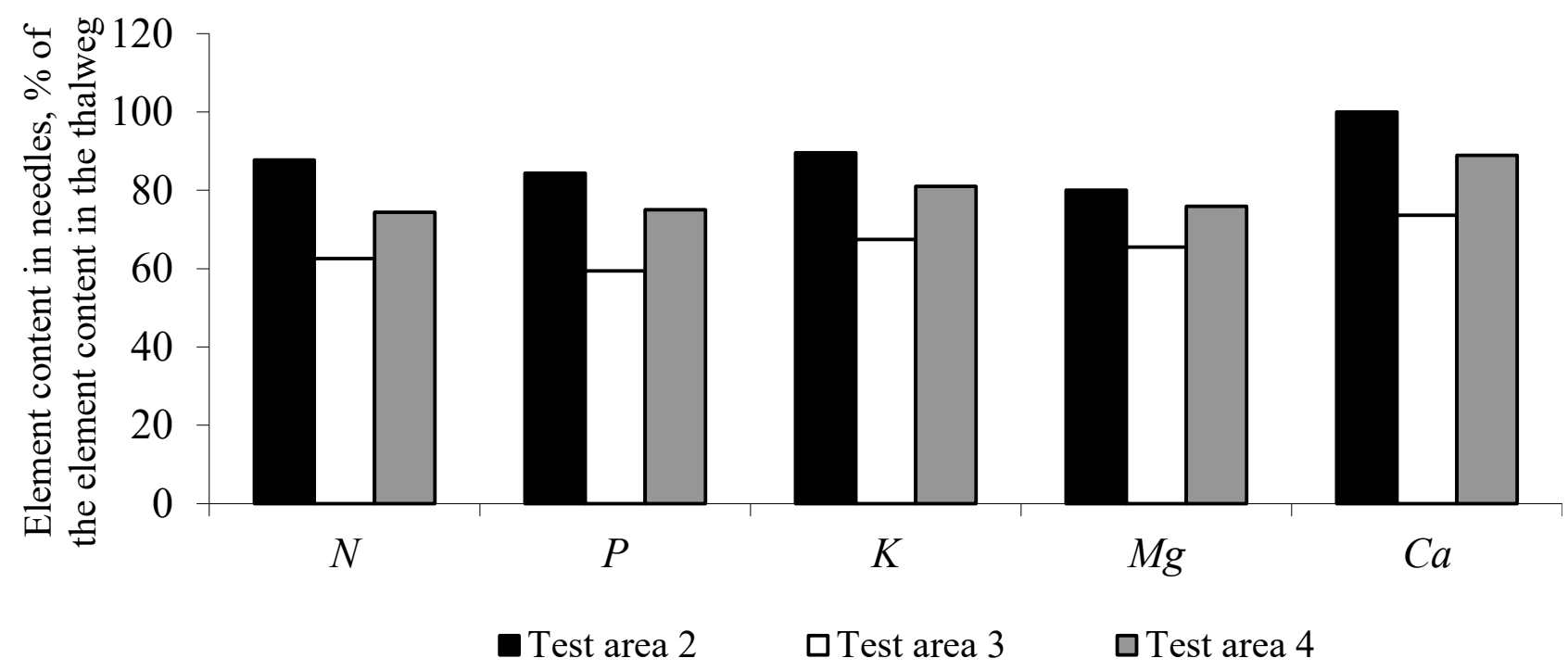

Fig. 3. Influence of forest-growth conditions on the content of nutrients in the needles of $P$. pallasiana, \% of the value in the thalweg. 
nutrition in the needles of plants in the lower part of the slope and the thalweg is insignificant at $\mathrm{p}<0.05$.

Some scholars indicate the optimal concentrations of nutrients in the leaves and needles of certain tree species (Mitchell, 1939; Tamm, 1956; Ingestad, 1962; Wehrmann, 1963). The optimal concentrations of nutrients in needles for the growth of $P$. strobus L. seedlings are $2.50-3.26 \%$ for nitrogen, $0.28-0.33 \%$ for calcium, $1.50-1.72 \%$ for potassium, and $0.56-0.67 \%$ for phosphorus of oven-dry weight (Mitchell, 1939). At lower concentrations, there were symptoms of a lack of nutrition elements. The values of the content of nitrogen and some other elements are revealed which impair the growth of P. sylvestris, Picea abies Karst., and Betula verrucosa Ehrh. because of their lack in the soil. These values are nitrogen $0.90-1.8 \%$, phosphorus $0.07-0.10 \%$, calcium $0.02-0.09 \%$, magnesium $0.09-0.13 \%$, and potassium $0.30-0.70 \%$ (Ingestad, 1962).

According to other scholars, the contents of spruce needles $\mathrm{P}-0.05-0.11 \%, \mathrm{Mg}-0.02-0.07 \%$, and $\mathrm{K}-0.15-0.33 \%$ are considered insufficient for normal growth of the treestand (Tamm, 1956; Wehrmann, 1963). The dependence between the content of nitrogen in the needles and the productivity of pine forests was proven (Wehrmann, 1963): productivity is very good $1.80 \%$ of oven-dry weight, moderately good $1.70-1.40 \%$, and poor $1.30 \%$. Churagulova (2004), analyzing the needs of P. sylvestris, Larix sukaczewii Djil., and Picea obovata Ledeb. in the elements of mineral nutrition, made a conclusion that the good growth of trees is provided by approximately the concentrations of elements in needle tissues (\%) as follows: nitrogen $>2.40-2.80$, potassium $>0.40-0.60$, and phosphorus $>0.50-0.80$. Landis, Haase, and Dumroese (2005) for conifer seedlings found that the optimal concentrations (\%) in needles are $\mathrm{N}-1.20-2.0, \mathrm{~K}-0.30-0.80$, $\mathrm{P}-0.10-0.20, \mathrm{Ca}-0.20-0.50$, and $\mathrm{Mg}-0.10-0.15$.

Proceeding from the range of concentrations of the elements given in the research works cited above, the nitrogen supply of the $P$. pallasiana needles growing in the thalweg and the lower part of the slope can be considered sufficient, and moderate in test areas 3 and 4 (on the Wehrmann scale, 1963). However, Ingestad (1962), Tamm (1956), Churagulova (2004) consider these values of the nitrogen supply insufficient for normal growth of the treestands. The amount of potassium in the needles of trees in all areas can be considered sufficient, although the data on the optimal content of this element in different papers are significantly different. None of the test areas showed a lack of calcium and magnesium. The content of these elements in the needles of $P$. pallasiana in all forest-growth conditions is within the range of concentrations given in literary sources as normal.

Comparison of the content of phosphorus with optimal values, indicated by other authors, suggests that it is relatively low only in the needles of trees in the middle part of the slope. Due to the important role of phosphorus in the life of plants, the lack of an element can be one of the causes of inhibition of growth processes of $P$. pallasiana precisely at the test area 3 compared to the indicators in the trees of thalweg. Wu et al. (2003) found differential patterns of gene expression in the vegetative organs of Arabidopsis plants for lack of phosphorus. Schwartau et al. (2009) note the presence of various adaptive responses in plants in response to phosphorus deficiency, manifested at different levels of the organization; genetic, molecular, biochemical, physiological, and morphological changes are detected.
Therefore, the leaf diagnosis indicates that there is sufficient content in the needles of $P$. pallasiana of such elements as potassium, calcium, magnesium and in three test areas that of phosphorus. The concentration of nitrogen can be viewed as insufficient in the needles of plants on the middle and upper parts of the slope (especially on the middle one) and of phosphorus in the middle area of the slope.

The research by Shcherbakov (1964) showed that there is a correlation between nitrogen content in the needles of last year's shoots and the tree growth increment values. However, it did not reveal the relationship between phosphorus content and tree productivity, although Wehrmann (1963) determined that as forest-site capacity increases, the amount of phosphorus in the needles increases too.

Thus, if in test areas 3 and 4, especially 4, the limiting factor of tree growth may be low moisture content of soil; then in test area site 3 , it is also the lack of nitrogen and phosphorus in needles. This can be explained by the fact that for somewhat lower moisture content of soil in the upper area of the slope, some indicators of growth in the trees of this area are better than those in the middle part. In general, despite the inhibition of growth in test areas 3 and 4, the condition of the treestands there can be considered as satisfactory, which indicates quite a high level of adaptation of $P$. pallasiana to the difficult conditions of growth in anti-erosion planting on the slope of the southern exposure.

\section{Conclusion}

Indicators of tree growth increment of $P$. pallasiana, length increment of lateral branches, and thickness of annual growth of shoots are maximal in the thalweg in conditions of the best water supply and the minimum in dry and semi-arid forest-growth conditions (test areas 3 and 4). At these sites, there is a minimum needle packing of annual shoots.

The content of total water in the needles P. pallasiana is consistent with the soil moisture supply. It is the highest in plants in fresh forest-growth conditions $\left(\mathrm{CL}_{2}\right)$ and the smallest in the dry area $\left(\mathrm{CL}_{0}\right)$, despite the fact that the pine is a pronounced xerophyte.

Leaf diagnostics testifies to the sufficient content of such elements in needles as potassium, calcium, and magnesium in all test areas and that of phosphorus in three areas except for the middle part of the slope. The concentration of nitrogen can be considered as insufficient in the needles of plants on the middle and upper parts of the slope, especially the middle one. Low moisture content in these areas and the lack of nitrogen, the most important element, can be the cause of growth retardation. Needles of the upper part of the slope are worse supplied with moisture, but better with nitrogen and phosphorus than in its middle area, which may be the cause of lower growth rates of plants in the latter.

\section{References}

Aber, J., Neilson, R.P., McNulty, St., Lenihan, J.M., Bachelet, D. \& Drapek R.J. (2001). Forest processes and global environmental change: predicting the effects of individual and multiply stressors. BioScience, 51(9), 735-751. DOI: 10.1641/0006-3568(2001)051[0735:FPAGEC]2.0.CO;2.

Aleinikovas, M. \& Grigaliūnas J. (2006). Differences of Pine (Pinus sylvestris L.) wood physical and mechanical properties from different forest site types in Lithuania. Baltic Forestry, 12(1), 9-13. 
Anuchin, N.P. (1982). Forest taxation (in Russian). Moscow: Forest Industry. Belgard, A.L. (1950). Forest vegetation of south-eastern part of Ukraine (in Russian). Kiev: Kiev State University Press.

Belgard, A.L. (1971). Steppe forestry (in Russian). Moscow: Forest Industry.

Bessonova, V.P., Korytova, A.I. \& Myhajlov O.F. (1975). Some features of the water regime of white acacia, growing in different conditions of moisture (in Russian). Issues of Steppe Forest Science and Nature Conservation, 5, 136-147.

Bessonova, V.P. (2001). Methods of phytoindication in the assessment of the environmental state of the environment (in Ukrainian). Zaporizhzhia: Zaporizhzhia State University Press.

Bessonova, V.P., Kuchma, V.N. \& Nemchenko M.V. (2015). Comparative characteristics of Pinus pallasiana at different levels of the slope of the beam in erosion plantations (in Russian). In Materials of the All-Russian Scientific and Practical Conference Actual problems, current state, innovations in the field of environmental engineering and construction' (pp. 44-49). November 11, 2015. Blagoveshhensk: Dal'nev. Publ., State Agrarian University.

Bessonova, V.P., Tkach, V.V. \& Kryvoruchko A.P. (2016). Water metabolism of leaves of Quercus robur in antierosion stands in the south of its range (in Ukrainian). Visnyk of Dnipropetrovsk University Biology Ecology 24(2), 444-450. DOI: 10.15421/011660.

Bessonova, V. \& Grytsay Z. (2018a). Content of plastid pigments in the needles of Pinus pallasiana D. Don in different forest growth conditions of anti-erosion planting. Ekológia (Bratislava), 37(4), 338-344. DOI 10.2478/eko-2018-0025.

Bessonova, V.P. \& Iusypiva T.I. (2018b). Morpho-anatomical parameters of the needles of Pinus pallasiana D. Don. in different forest growth conditions of the antierosion afforestation (in Ukrainian). Ukrainian Journal of Ecology, 8(1), 851-858. DOI: 10.15421/2017_285.

Çalişkan, S. \& Boydak M. (2017). Afforestation of arid and semiarid ecosystems in Turkey. Turkish Journal of Agriculture and Forestry, 41, 317-330. DOI: $10.3906 /$ tar-1702-39.

Churagulova, Z.S. (2004). Soils of forest nurseries of the southern Urals and the optimization of their forest-growing properties (in Russian). Synopsis of the PhD Thesis of Dr. Biol. Sciences, Tomsk.

Colom, M.R. \& Vazzana C. (2001). Drought stress on three cultivars of Eragrostis curvula: photosynthesis and water relations. Plant Growth Regul. 34 (2), 195-202. DOI: 10.1023/A:1013392421117.

Correia, M.J., Coelho, D. \& David M.M. (2001). Response to seasonal drought in three cultivars of Ceratonia siliqua, leaf growth and water relation. Tree Physiol., 21(10), 645-653. DOI: 10.1093/treephys/21.10.645.

Fotelli, M.N., Radoglou, K.M. \& Constantinidou H.-I.A. (2000). Water stress responses of seedlings of four Mediterranean oak species. Tree Physiol., 20(16), 1065-1075. DOI: 10.1093/treephys/20.16.1065.

Furdychko, O.I., Hladun, H.B. \& Lavrov V.V. (2006). Forest in the steppe: the basis of sustainable development (in Ukrainian). Kiev: Osnova Publ.

Gorejko, V.A. (1992). Fastening the steep slopes of ravine-girder lands (in Russian). Forestry Information, 11, 36-39.

Hawkesford, M., Horst, W., Kichey, T., Lambers, H., Schjoerring, J., Møller I.S. \& White P. (2012). Functions of macronutrients. In P. Marschner (Ed.), Marschner's mineral nutrition of higher plants (pp. 135-189). DOI: 10.1016/B978-0-12-384905-2.00006-6

Hrytsaenko, Z.M., Hrytsaenko, A.O. \& Karpenko V.P. (2003). Methods of biological and agrochemical studies of plants and soils (in Ukrainian). Kiev: NICHLAVA.

Hughes, L. (2000). Biological consequences of global warming: is the signal already? Trends Ecol. Evol., 15(2), 56-61. DOI: 10.1016/S01695347(99)01764-4.

Ingestad, T. (1962). Macroelement nutrition of pine, spruce, and birch seedings in nutrient solution. Medd. Statens Sogsförsöksn-Satalt, 51(7), 150.

Karasiuk, I.M., Herkiial, O.M., Nedviga, M.V., Hospodarenko, G.M., Bilan, I.A., Martyniuk, A.T., Kolar'kov, Yu.V., Khomchak, M.Yu., Cherno, O.D., Zamors'kyj, O.O. \& Nevlad V.I. (2001). Agrochemical analysis of soil, plants and fertilizers at laboratory and practical classes on agrochemical chemistry (in Ukrainian). Kiev: NICHLAVA.

Landis, T.D., Haase, D.L. \& Dumroese R.K. (2005). Plant nutrient testing and analysis in forest and conservation nurseries. In R.K. Dumroese, L.E. Riley \& T.D. Landis (Eds.), National proceedings: Forest and Conservation Nursery Associations-2004 (pp. 76-83). Fort Collins: U.S. Department of Agriculture, Forest Service, Rocky Mountain Research Station.
Lir, Kh., Pol'ster, G. \& Fidler G.-I. (1974). Physiology of woody plants (in Russian). Moscow: Forest Industry.

Mercado, L.M., Patin, S., Domingues, T.F., Fyllas, N.M., Weedon, G.P., Sitch S., Quesada, C.A., Phillips, O.L., Araga, L.E.O.C., Malhi, Y., Dolman, A.J., Restrepo-Coupe, N., Saleska, S.R., Baker, T.R., Almeida, S., Higuchi, N. \& Lloyd J. (2017). Variations in Amazon forest productivity correlated with foliar nutrients and modelled rates of photosynthetic carbon supply. Philos. Trans. R. Soc. Lond. B, 366, 3316-3329. DOI: 10.1098/rstb.2011.0045.

Mitchell, H.L. (1939). The growth and nutrition of white pine (Pinus strobus L.) seedlings in cultures with varying nitrogen, phosphorus, potassium and calcium. Black Rock Forest Bulletin, 9.

Moroz, O.B (1972). Materials to the characteristic of anti-erosion installations in conditions of the Samaria (in Russian). In Issues of Steppe Forest Science (pp. 44-47). Dnipropetrovsk.

Morozov, G.F. (1931). The doctrine of the forest (in Russian). Moscow, Leningrad: Sel'hozgiz Publ.

Netzer, F., Mueller, C.W., Scheerer, U., Grüner., J., Kögel-Knabner, I., Herschbach, C. \& Rennenberg H. (2018). Phosphorus nutrition of Populus $\times$ canescens reflects adaptation to high P-availability in the soil. Tree Physiol., 38(1), 6-24. DOI: 10.1093/treephys/tpx126.

Odukalets, I.O. \& Musienko M.M. (2012). Influence of mineral element contamination on Pinus L. species in natural park "Podilski Tovtry" (in Ukrainian). Biological Bulletin of Bogdan Chmelnitskiy Melitopol State Pedagogical University, 2, 108-115. DOI: 10.15421/20122_27.

Olkhovsky, A.F. (1984). Experience in the use of conifers in plantations on the eroded lands of Podolsky Transnistria (in Russian). PhD Thesis in Agricultural Sciences, Kharkiv.

Pane, J.A. \& Goldstein A.H. (2001). Response of stomatal conductance to drought in ponderosa pine: implications for carbon and ozone uptake. Tree Physiol., 21(5), 335-342. DOI: 10.1093/treephys/21.5.337.

Pietrzykowski, M., Woś, B. \& Haus N. (2013). Scots pine needles macronutrient $(\mathrm{N}, \mathrm{P}, \mathrm{K}, \mathrm{CA}, \mathrm{MG}$, and S) supply at different reclaimed mine soil substrates - as an indicator of the stability of developed forest ecosystems. Environ. Monit. Assess., 185(9), 7445-7457. DOI: 10.1007/s10661013-3111-9.

Ponomaryova, T.V., Kuzmina, N.A. \& Kuzmin S.R. (2009). Soil water reserve influence on coniferous species growth in the experimental conditions. The Bulletin of KrasGAU, 12, 45-49.

Rausch, C. \& Bucher M. (2002). Molecular mechanisms of phosphate transport in plants. Planta, 216(1), 23-37. DOI: 10.1007/s00425-002-0921-3.

Samuilov, F.D. (1971). The effect of phosphate nutrition on water metabolism and the state of water in plants under adverse moisture conditions (in Russian). In State of water and water exchange in cultivated plants (pp. 146-153). Moscow: Science.

Schwartau, V.V., Gulyaev, B.I. \& Karlova A.B. (2009). Peculiarities of plants reaction on phosphorus deficiency. Plant Physiol., 41(3), 208-220.

Shao, H.B., Chu, L.Y., Jaleel, Ch.A. \& Zhao Ch.X. (2008). Water deficit stress induced anatomical changes in higher plants. C. R. Biol., 331, 215-225. DOI: $10.1016 /$ j.crvi.2008.01.002

Shcherbakov, A.P. (1964). Experience in the use of sheet diagnosis to determine the needs of pine in nitrogen and phosphorus (in Russian). In Physiological rationale for plant nutrition (pp. 324-332). Moscow: Science.

Shvets', Yu.P. (2010). Analysis of Crimean pine forests productivity (in Ukrainian). In Proceedings of the scientific conference 'Forestry Science: Origins, Contemporary, Prospects' (pp. 74-75). October 12-14, 2010, Kharkiv. Kharkiv: UkrNIILGA Publ.

Smirnoff, N. (1998). Plant resistance to environmental stress. Curr. Opin. Biotechnol., 9, 214-219.

Tamm, C.O. (1956). Studier over skogens näringsförhällan den. Medd. Stattens Skogsförsäksanstalt, 46.

Tang, Z., Xu, W., Zhou, G., Bai, Y., Li, J., Tang, X., Chen, D., Liu, Q., Ma, W., Xiong, G., He, H., He, N., Guo, Y., Guo, Q., Zhu, J., Han, W., Hu, H., Fang, J. \& Xie Z. (2018). Patterns of plant carbon, nitrogen, and phosphorus concentration in relation to productivity in China's terrestrial ecosystems. Proc. Nat. Acad. Sci. USA, 115(16), 4033-4038. DOI: 10.1073/pnas.1700295114.

Tarkhanov, S.N. \& Biryukov S.Yu. (2012). Influence of atmospheric pollution on the morphological parameters of the assimilation apparatus of pine and spruce in the basin of the Northern Dvina. Contemporary Problems of Ecology, 5, 300-306. DOI: 10.1134/S1995425512030158. 
Thakur, P.S. \& Kaur H. (2001).Variation in photosynthesis, transpiration, water use efficiency, light transmission and leaf area index in multipurpose agroforestry tree species. Indian J. Plant Physiol., 6(3), 249-253.

Thakur, P.S. \& Sood R. (2005). Drought tolerance of multipurpose agroforestry tree species during first and second summer droughts after transplanting. Indian J. Plant Physiol., 10(1), 32-40.

Tsvetkova, N.N. (2013). Features of migration of organic and mineral substances and trace elements in forest-steppe ecosystems of Ukraine (in Russian). Dnipropetrovsk: Dnipropetrovsk University Press.

Velinova, K. \& Naydenova T. (2008). Contents of pigments, total protein and free proline in the assimilating apparatus of scots pine (Pinus sylvestris L.) and Austrian black pine (Pinus nigra Arn.) in different soil moisture. For. Sci., 45(1), 3-15.

Walther, G.R. (2003). Plants in a warmer world. Perspect. Plant Ecol. Evol. Syst., 6(3), 169-185. DOI: 10.1078/1433-8319-00076.
Wehrmann, J. (1963). Möglichkeiten und Grenzen der Blattanalyse in der Forstwirtschaft. Landwirtschaftliche Forschung, 16(2), 12-23.

Wu, P., Ma, L., Hou, X., Wang, M., Wu, Y., Liu, F. \& Deng X.W (2003) Phosphate starvation triggers distinct alterations of genome expression in Arabidopsis roots and leaves. Plant Physiol., 132, 1260-1271. DOI: 10.1104/pp.103.021022.

Yan, Z., Li, P., Chen, Y., Han, W. \& Fang J. (2016). Nutrient allocation strategies of woody plants: an approach from the scaling of nitrogen and phosphorus between twig stems and leaves. Scientific Reports, 6, 20099. DOI: 10.1038/srep20099.

Zahner, R. \& Donely J.R. (1967). Refining correlation of water deficits and radial growth in red pine. Ecology, 48, 425-430. DOI: 10.2307/1936494.

Zaitseva, I. \& Syrovatko V. (2016). Molecular diffusion water exchange in compartments of tissue water of Maize. International Letters of Natural Sciences, 51, 21-28. DOI: 10.18052/www.scipress.com/ILNS.51.21. 